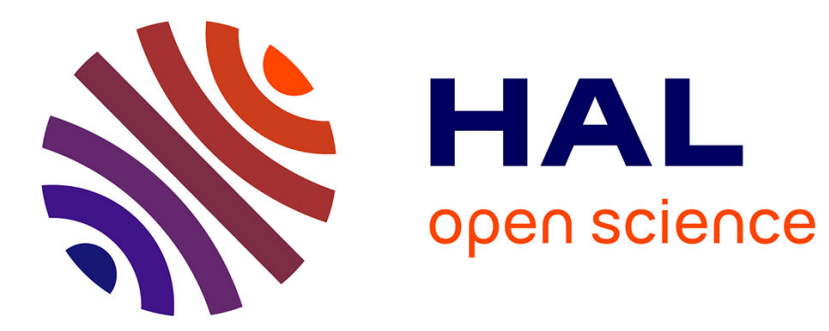

\title{
Plumbing the uncertainties of solvothermal synthesis involving uranyl ion carboxylate complexes.
}

\author{
Jack Harrowfield, Youssef Atoini, Pierre Thuéry
}

\section{To cite this version:}

Jack Harrowfield, Youssef Atoini, Pierre Thuéry. Plumbing the uncertainties of solvothermal synthesis involving uranyl ion carboxylate complexes.. CrystEngComm, 2022, 24, pp.1475-1484. 10.1039/D1CE01663F . cea-03543383

\section{HAL Id: cea-03543383 https://hal-cea.archives-ouvertes.fr/cea-03543383}

Submitted on 26 Jan 2022

HAL is a multi-disciplinary open access archive for the deposit and dissemination of scientific research documents, whether they are published or not. The documents may come from teaching and research institutions in France or abroad, or from public or private research centers.
L'archive ouverte pluridisciplinaire HAL, est destinée au dépôt et à la diffusion de documents scientifiques de niveau recherche, publiés ou non, émanant des établissements d'enseignement et de recherche français ou étrangers, des laboratoires publics ou privés. 


\title{
Plumbing the uncertainties of solvothermal synthesis involving uranyl ion carboxylate complexes $\uparrow$
}

\author{
Jack Harrowfield, ${ }^{* a}$ Youssef Atoini ${ }^{\mathrm{b}}$ and Pierre Thuéry*c
}

Some of the uncertainties inherent to solvo-hydrothermal synthetic methods which often hinder isolation of the desired product are discussed and illustrated by the structural characterisation of four uranyl ion complexes with long-chain saturated or unsaturated aliphatic dicarboxylate ligands, this being placed in the context of previous results. [Zn(phen) $\left.)_{2}(\mathrm{HCOO})\right]\left[\mathrm{UO}_{2}(\mathrm{muc})(\mathrm{HCOO})\right](\mathbf{1})$, where $\mathrm{H}_{2}$ muc is trans, trans-muconic (trans, trans-1,6-hexa2,4-dienedioic) acid, includes formate anions, generated in situ from $N, N$-dimethylformamide (DMF) hydrolysis, as chelating ligands on both metal centres, which limits polymer periodicity. [UO ${ }_{2}$ (muc)(NMP)] (2) was obtained in the presence of $\mathrm{PPh}_{4}{ }^{+}$cations, but coordination of $\mathrm{N}$-methyl-2-pyrrolidone (NMP) results in formation of a neutral monoperiodic polymer instead of an anionic one. Similarly, NMP complexation prevents inclusion of $\left[\mathrm{Co}(\mathrm{en})_{3}\right]^{3+}$ cations in $\left[\mathrm{UO}_{2}(\mathrm{C} 8)(\mathrm{NMP})\right](3)$, where $\mathrm{H}_{2} \mathrm{C} 8$ is 1,8 -octanedioic acid, another monoperiodic coordination polymer. No solvent is coordinated in $\left[\mathrm{H}_{2} \mathrm{NMe}_{2}\right]_{2}\left[\left(\mathrm{UO}_{2}\right)_{2}(\mathrm{C} 13)_{3}\right](4)$, where $\mathrm{H}_{2} \mathrm{C} 13$ is $1,13-$ tridecanedioic acid, but the desired $\left[\mathrm{Co}(\mathrm{en})_{3}\right]^{3+}$ counterions are displaced by $\mathrm{H}_{2} \mathrm{NMe}_{2}{ }^{2+}$ cations generated in situ from DMF hydrolysis, giving a diperiodic network with the Kla topological type, isomorphous to that formed from 1,15-pentadecanedioic acid. Complexes 1 and $\mathbf{2}$ are non-emissive in the solid state, while $\mathbf{4}$ displays a broad uranyl emission peak with unresolved fine structure.

\footnotetext{
a Université de Strasbourg, ISIS, 8 allée Gaspard Monge, 67083 Strasbourg, France; E-mail: harrowfield@unistra.fr

${ }^{b}$ Biogenic Functional Materials Group, Technical University of Munich, Campus Straubing, Schulgasse 22, 94315 Straubing, Germany

${ }^{c}$ Université Paris-Saclay, CEA, CNRS, NIMBE, 91191 Gif-sur-Yvette, France; E-mail: pierre.thuery@cea.fr $\uparrow$ CCDC 2126523-2126526. For crystallographic data in CIF or other electronic format see DOI:
} 


\section{Introduction}

The remarkable facility with which crystallographic studies can be conducted using contemporary equipment and procedures has led to an explosion in the number, in particular, of single-crystal structure determinations, as witnessed by the tremendous growth of the Cambridge Crystallographic Database in recent years. ${ }^{1}$ A concomitant of this explosion has been the necessary development of efficient methods for crystal formation and the most prominent of these for the formation of coordination polymer crystals is that known as solvothermal synthesis. ${ }^{2,3}$ A disadvantage of this method is that very little is known of the solution equilibria and reaction kinetics under the conditions of high temperatures and pressures, commonly involving the use of mixed solvents, so that its development has been largely empirical, ${ }^{4-8}$ although some progress has been made for uranyl ion complexation in particular. ${ }^{9,10}$ In many instances, the nature of the isolated product provides evidence for the occurrence of unanticipated reactions within the reagent mixture and certain examples of this, such as the (probably metal-ion catalysed ${ }^{11}$ ) hydrolysis of $N, N$-dimethylformamide (DMF) to give formate and dimethylammonium ions, have become rather well-recognised $\left(e . g .{ }^{12-15}\right)$ and indeed deliberately exploited. ${ }^{16,17}$ Conversely, there are also instances where a reagent deliberately added to the reaction mixture does not appear in the product but can nonetheless influence its nature $\left(\right.$ e.g. $\left.{ }^{18,19}\right)$. Another complicating factor is whether or not the product is isolated under the reaction conditions or whether it is deposited after returning to ambient conditions. Observations $\left(\right.$ e.g. $\left.{ }^{13}\right)$ that crystalline materials deposited in the hot, pressurised media become accompanied by amorphous materials on cooling indicate that the temperature of crystallisation can be a critical factor. The long reaction times typical of most solvothermal syntheses, a drawback which can be overcome with "post-synthetic modification" procedures, ${ }^{20,21}$ raise questions as to the nature of kinetic factors which may be operative. ${ }^{22}$ 
Given the common use of uranyl nitrate in acidic solutions exposed to light in solvothermal syntheses of uranyl coordination polymers, redox chemistry might well be anticipated to play some role. In the formation of uranyl-carboxylate coordination polymers by solvothermal methods, the involvement of peroxide ligand in the product has but rarely been observed $^{23}$ though it is familiar for various complexes synthesised under milder conditions and understood to be initiated by photocatalysed $\mathrm{U}^{\mathrm{VI}}$ reduction to $\mathrm{U}^{\mathrm{V}},{ }^{24}$ whereas the more commonly observed conversion of some organic ligands to product-bound oxalate ${ }^{25}$ can only be rationalised generally in terms of the oxidising nature of the reaction media involved. Surprisingly, given the well-established capacity of uranyl ion to undergo reduction by abstraction of a hydrogen atom from organic molecules in solution reactions, ${ }^{26,27}$ evidence of such a reaction leading to involvement of radical species in solvothermal syntheses is very limited. ${ }^{28}$ Non-redox processes are better understood and in our work in general employing solvothermal syntheses and concerning uranyl carboxylates, the presence of dimethylammonium ions arising from DMF hydrolysis has been a common discovery, ${ }^{29}$ along with less frequently observed processes including cyclisation of a carboxycinnamate ${ }^{29 e}$ and inversion of $>\mathrm{CH}\left(\mathrm{CO}_{2}\right)^{-}$centres, ${ }^{29 h, 30}$ both explicable in conventional mechanistic terms but which attest further to the variety of reactions possible under extreme conditions. While acidity of the reaction medium is a well-recognised factor ${ }^{31}$ and has led to many carboxylate complexes being prepared from the corresponding carboxylic acid in order to minimise hydrolytic oligomerisation of uranyl units, this is not a guarantee that oligomerisation will not occur and it can only be said that there is a complicated interaction between acid-base, complexation and solubility equilibria. The last of these is of course the reason why the structure of any isolated crystal cannot be simply interpreted in terms of the stability of solution species, though the structures themselves do provide some information on the factors determining the solubility. 
Added to all this is the complication mentioned above that the nature of the products of solvothermal syntheses may not necessarily be determined by reactions at equilibrium.

Hydrogen bonding of a countercation to anionic uranyl ion coordination polymers formed with polycarboxylate ligands has proven to be an important influence on the structure of those polymers. ${ }^{32-35}$ In particular where $\mathrm{NH} \cdots \mathrm{O}$ interactions are involved $\left(e . .^{12,29 a, 29 c, 36}\right)$, we have frequently observed (e.g. $\left.{ }^{12,29 a, 29 c, 36}\right)$ this influence as a result of the fortuitous presence of dimethylammonium cation produced through DMF hydrolysis and have endeavoured to exploit it further through the deliberate addition of multiple hydrogen bond donors with varying stereochemistry such as guanidinium ion and several polyamine metal ion complexes. In part, the choice of these additives was based on their non-basic nature, assuming that this would prevent uranyl ion hydrolysis to give oligomeric $\mathrm{U}^{\mathrm{VI}}$-oxido-hydroxido units by a lack of any effect on the acidic conditions resulting from the deprotonation of reactant polycarboxylic acids (though this is an oversimplified analysis of the situation). Even where the polyamine complex has no sites available for further coordination interactions, it can be of some utility for the isolation of crystalline products. In the case of $\left[\mathrm{Co}(\mathrm{en})_{3}\right]^{3+}$, for example,${ }^{12,36-39}$ this is due to the presence in this cation of up to $12 \mathrm{NH}$-donor sites known to engage in hydrogen bonding interactions, as found in the structures of a wide variety of simple salts of this cation. ${ }^{40}$

The present report is intended to illustrate some of the uncertainties associated with the solvothermal method of synthesis by using the structures of four uranyl ion coordination polymers involving dicarboxylate ligands derived from acids containing long aliphatic chains, a large family of ligands which has been extensively investigated (e.g. $\left.{ }^{19,23,29 i, 39}\right)$ and thus lends itself to comparisons of the effects of synthetic conditions on the structures of the complexes formed. The ligands used are either unsaturated in the case of trans, trans-muconic (trans,trans1,6-hexa-2,4-dienedioic) acid ( $\mathrm{H}_{2}$ muc), or saturated in the case of suberic (octanedioic) acid $\left(\mathrm{H}_{2} \mathrm{C} 8\right)$ and brassilic (tridecanedioic) acid $\left(\mathrm{H}_{2} \mathrm{C} 13\right)$, this diverse array being chosen to illustrate 
cases where the crystal composition is determined by component reactions in solution leading to products rather unlike those obtained for close relatives under similar conditions. Systematic variations of the same additives and organic cosolvents have been made with all the present ligands but only in few cases have single-crystals suitable for structure determination been obtained, so that the series of complexes reported somewhat lacks in homogeneity, but allows nevertheless comparison with the results of previous studies. In particular, two of these complexes were synthesised in the presence of $\left[\mathrm{Co}(\mathrm{en})_{3}\right]^{3+}$, but in neither case did this cation appear in the product. The question arises as to whether, despite its absence from the isolated reaction products, the $\left[\mathrm{Co}(\mathrm{en})_{3}\right]^{3+}$ cation nonetheless had an influence on the nature of those products, a circumstance which is certainly possible, in particular through effects on solution equilibria which determine the product solubility. ${ }^{41}$

\section{Experimental}

\section{Synthesis}

Caution! Uranium is a radioactive and chemically toxic element, and uranium-containing samples must be handled with suitable care and protection. Small quantities of reagents and solvents were employed to minimize any potential hazards arising both from the presence of uranium and the use of pressurised vessels for the syntheses.

$\left[\mathrm{UO}_{2}\left(\mathrm{NO}_{3}\right)_{2}\left(\mathrm{H}_{2} \mathrm{O}\right)_{2}\right] \cdot 4 \mathrm{H}_{2} \mathrm{O}$ (RP Normapur, 99\%) was purchased from Prolabo, the carboxylic acids and $\mathrm{Zn}\left(\mathrm{NO}_{3}\right)_{2} \cdot 6 \mathrm{H}_{2} \mathrm{O}$ were from Aldrich, and 1,10-phenanthroline (phen) and $\left[\mathrm{Co}(\mathrm{en})_{3}\right] \mathrm{Cl}_{3} \cdot 3 \mathrm{H}_{2} \mathrm{O}$ were from Alfa-Aesar. All reagents were used as received. Elemental analyses were performed by MEDAC Ltd. For all syntheses, the mixtures in demineralised water/organic solvent were placed in $10 \mathrm{~mL}$ tightly closed glass vessels and heated at $140{ }^{\circ} \mathrm{C}$ 
in a sand bath, under autogenous pressure. The crystals characterised were those deposited under the reaction conditions and not from subsequent cooling and depressurisation.

[Zn(phen)2(HCOO)][UO 2 (muc)(HCOO)] (1). trans, trans-Muconic acid (14 mg, 0.10 mmol), [ $\left.\mathrm{UO}_{2}\left(\mathrm{NO}_{3}\right)_{2}\left(\mathrm{H}_{2} \mathrm{O}\right)_{2}\right] \cdot 4 \mathrm{H}_{2} \mathrm{O}(35 \mathrm{mg}, 0.07 \mathrm{mmol}), \mathrm{Zn}\left(\mathrm{NO}_{3}\right)_{2} \cdot 6 \mathrm{H}_{2} \mathrm{O}(30 \mathrm{mg}, 0.10 \mathrm{mmol})$, and 1,10-phenanthroline $(36 \mathrm{mg}, 0.20 \mathrm{mmol})$ were dissolved in a mixture of water $(1.0 \mathrm{~mL})$ and DMF (0.2 mL). Yellow crystals of complex 1 were obtained within four days (48 mg, 74\% yield based on U). Anal. Calcd for $\mathrm{C}_{32} \mathrm{H}_{22} \mathrm{~N}_{4} \mathrm{O}_{10} \mathrm{UZn}$ : C, 41.51; H, 2.39; N, 6.05. Found: $\mathrm{C}$, 40.97; H, 2.48; N, 6.32\%.

[UO2(muc)(NMP)] (2). trans,trans-Muconic acid (14 $\mathrm{mg}, \quad 0.10$ mmol), $\left[\mathrm{UO}_{2}\left(\mathrm{NO}_{3}\right)_{2}\left(\mathrm{H}_{2} \mathrm{O}\right)_{2}\right] \cdot 4 \mathrm{H}_{2} \mathrm{O}(35 \mathrm{mg}, 0.07 \mathrm{mmol})$, and $\mathrm{PPh}_{4} \mathrm{Br}(42 \mathrm{mg}, 0.10 \mathrm{mmol})$ were dissolved in a mixture of water $(0.7 \mathrm{~mL})$ and $\mathrm{N}$-methyl-2-pyrrolidone (NMP, $0.2 \mathrm{~mL})$. Yellow crystals of complex 2 were obtained within four days ( $25 \mathrm{mg}, 70 \%$ yield based on U). Anal. Calcd for $\mathrm{C}_{11} \mathrm{H}_{13} \mathrm{NO}_{7} \mathrm{U}: \mathrm{C}, 25.94 ; \mathrm{H}, 2.57 ; \mathrm{N}, 2.75$. Found: C, 25.76; H, 2.77; N, 2.64\%.

[UOO 2 (C8)(NMP)] (3). $\mathrm{H}_{2} \mathrm{C} 8(18 \mathrm{mg}, 0.10 \mathrm{mmol}),\left[\mathrm{UO}_{2}\left(\mathrm{NO}_{3}\right)_{2}\left(\mathrm{H}_{2} \mathrm{O}\right)_{2}\right] \cdot 4 \mathrm{H}_{2} \mathrm{O}(35 \mathrm{mg}$, $0.07 \mathrm{mmol})$, and $\left[\mathrm{Co}(\mathrm{en})_{3}\right] \mathrm{Cl}_{3} \cdot 3 \mathrm{H}_{2} \mathrm{O}(24 \mathrm{mg}, 0.05 \mathrm{mmol})$ were dissolved in a mixture of water $(0.7 \mathrm{~mL})$ and NMP $(0.2 \mathrm{~mL})$. A few yellow crystals of complex 3 were obtained within one week.

[H $\left.\mathbf{H}_{2} \mathrm{NMe}_{2}\right]_{2}\left[\left(\mathrm{UO}_{2}\right)_{2}(\mathbf{C 1 3})_{3}\right]$ (4). $\mathrm{H}_{2} \mathrm{C} 13(25 \mathrm{mg}, 0.10 \mathrm{mmol}),\left[\mathrm{UO}_{2}\left(\mathrm{NO}_{3}\right)_{2}\left(\mathrm{H}_{2} \mathrm{O}\right)_{2}\right] \cdot 4 \mathrm{H}_{2} \mathrm{O}$ (35 mg, $0.07 \mathrm{mmol})$, and $\left[\mathrm{Co}(\mathrm{en})_{3}\right] \mathrm{Cl}_{3} \cdot 3 \mathrm{H}_{2} \mathrm{O}(24 \mathrm{mg}, 0.05 \mathrm{mmol})$ were dissolved in a mixture of water $(0.9 \mathrm{~mL})$ and DMF $(0.2 \mathrm{~mL})$. Yellow crystals of complex 4 were obtained within one week (22 mg, 46\% yield based on U). Anal. Calcd for $\mathrm{C}_{43} \mathrm{H}_{82} \mathrm{~N}_{2} \mathrm{O}_{16} \mathrm{U}_{2}: \mathrm{C}, 38.00 ; \mathrm{H}, 6.08 ; \mathrm{N}$, 2.06. Found: C, 38.92; H, 6.00; N, 1.85\%. 


\section{Crystallography}

Data collections were performed on a Bruker D8 Quest diffractometer using an Incoatec Microfocus Source (I $\mu$ S 3.0 Mo) and a PHOTON III area detector, and operated with APEX3 ${ }^{42}$ The data were processed with SAINT, ${ }^{43}$ and empirical absorption corrections were made with SADABS. ${ }^{44}$ The structures were solved by intrinsic phasing with SHELXT, ${ }^{45}$ and refined by full-matrix least-squares on $F^{2}$ with SHELXL, ${ }^{46}$ using the ShelXle interface. ${ }^{47}$ All nonhydrogen atoms were refined with anisotropic displacement parameters. The hydrogen atoms were introduced at calculated positions and treated as riding atoms with an isotropic displacement parameter equal to 1.2 times that of the parent atom (1.5 for $\left.\mathrm{CH}_{3}\right)$. The SQUEEZE software ${ }^{48}$ was used to subtract the contribution of disordered solvent molecules to the structure factors for compound 4. In complexes $\mathbf{2}$ and $\mathbf{3}$, the NMP molecule is disordered over two positions sharing either the oxygen and three carbon atoms or only the oxygen atom, respectively, which have been refined with occupancy parameters constrained to sum to unity and, for complex $\mathbf{3}$, some restraints on bond lengths and displacement parameters for the atoms of the minor component. Crystal data and structure refinement parameters are given in Table 1. Drawings were made with ORTEP- $3^{49}$ and VESTA. ${ }^{50}$ Topological analysis of complex 4 was made with ToposPro. ${ }^{51}$

\section{Luminescence measurements}

Emission spectra were recorded on solid samples using an Edinburgh Instruments FS5 spectrofluorimeter equipped with a $150 \mathrm{~W} \mathrm{CW}$ ozone-free xenon arc lamp, dual-grating excitation and emission monochromators $(2.1 \mathrm{~nm} / \mathrm{mm}$ dispersion; 1200 grooves $/ \mathrm{mm})$ and an R928P photomultiplier detector. The powdered compounds were pressed to the wall of a quartz tube, and the measurements were performed using the right-angle mode in the SC-O5 cassette. An excitation wavelength of $420 \mathrm{~nm}$ was used in all cases and the emission was monitored 
between 450 and $600 \mathrm{~nm}$. The quantum yield measurements were performed by using a Hamamatsu Quantaurus C11347 absolute photoluminescence quantum yield spectrometer and exciting the samples between 300 and $400 \mathrm{~nm}$.

Table 1 Crystal data and structure refinement details

\begin{tabular}{lllll}
\hline & $\mathbf{1}$ & $\mathbf{2}$ & $\mathbf{3}$ & $\mathbf{4}$ \\
\hline & & & & \\
Chemical formula & $\mathrm{C}_{32} \mathrm{H}_{22} \mathrm{~N}_{4} \mathrm{O}_{10} \mathrm{UZn}$ & $\mathrm{C}_{11} \mathrm{H}_{13} \mathrm{NO}_{7} \mathrm{U}$ & $\mathrm{C}_{13} \mathrm{H}_{21} \mathrm{NO}_{7} \mathrm{U}$ & $\mathrm{C}_{43} \mathrm{H}_{82} \mathrm{~N}_{2} \mathrm{O}_{16} \mathrm{U}_{2}$ \\
$M / \mathrm{g} \mathrm{mol}^{-1}$ & 925.93 & 509.25 & 541.34 & 1359.16 \\
Crystal system & monoclinic & triclinic & monoclinic & monoclinic \\
Space group & $P 2 / n$ & $P \overline{1}$ & $C 2 / c$ & $C 2 / c$ \\
$a / \AA$ & $12.0722(5)$ & $7.3392(4)$ & $16.4803(5)$ & $30.9868(18)$ \\
$b / \AA$ & $8.0184(4)$ & $8.7663(4)$ & $8.2141(2)$ & $13.0858(7)$ \\
$c / \AA$ & $16.9466(7)$ & $11.8187(5)$ & $24.4218(7)$ & $16.4519(9)$ \\
$\alpha /{ }^{\circ}$ & 90 & $109.0421(16)$ & 90 & 90 \\
$\beta /{ }^{\circ}$ & $108.4076(17)$ & $92.0632(19)$ & $98.7372(12)$ & $115.924(3)$ \\
$\gamma /{ }^{\circ}$ & 90 & $108.7106(17)$ & 90 & 90 \\
$V / \AA^{3}$ & $1556.49(12)$ & $672.34(6)$ & $3267.63(16)$ & $5999.8(6)$ \\
$Z$ & 2 & 2 & 8 & 4 \\
Reflections collected & 60449 & 57490 & 65423 & 57267 \\
Independent reflections & 4741 & 4093 & 3081 & 5682 \\
Observed reflections $[I>2 \sigma(I)]$ & 4545 & 3967 & 3015 & 4728 \\
$R$ int & 0.048 & 0.045 & 0.054 & 0.081 \\
Parameters refined & 219 & 209 & 254 & 287 \\
$R 1$ & 0.016 & 0.014 & 0.018 & 0.030 \\
$w R_{2}$ & 0.040 & 0.033 & 0.037 & 0.076 \\
$S$ & 1.063 & 1.074 & 1.272 & 1.074 \\
$\Delta \rho_{\text {min }} / \mathrm{e} \AA^{-3}$ & -0.63 & -0.53 & -1.05 & -1.23 \\
$\Delta \rho_{\text {max }} / \mathrm{e} \AA^{-3}$ & 1.61 & 2.00 & 0.88 & 2.24 \\
& & & & \\
\hline & & & & \\
\hline
\end{tabular}

\section{Results and discussion}

\section{Crystal structures}

In the complex $\left[\mathrm{Zn}(\text { phen })_{2}(\mathrm{HCOO})\right]\left[\mathrm{UO}_{2}(\mathrm{muc})(\mathrm{HCOO})\right](\mathbf{1})$, shown in Figure 1, the formate ligand derived from DMF hydrolysis serves to convert what would otherwise be a neutral $\left[\mathrm{UO}_{2}(\mathrm{muc})\right]$ unit into one that is anionic and has a role somewhat different to that in most related species. In particular, formate is not present in the uranyl muconate complex obtained with DMF as cosolvent in the presence of $\left[\mathrm{Ni}(\text { bipy })_{3}\right]^{2+}$ (bipy $=2,2^{\prime}$-bipyridine $),{ }^{52}$ nor in any of a series of complexes with saturated dicarboxylate ligands $\mathrm{C} n^{2-}$ with $n=7,8,9,10,12$ and 13, 


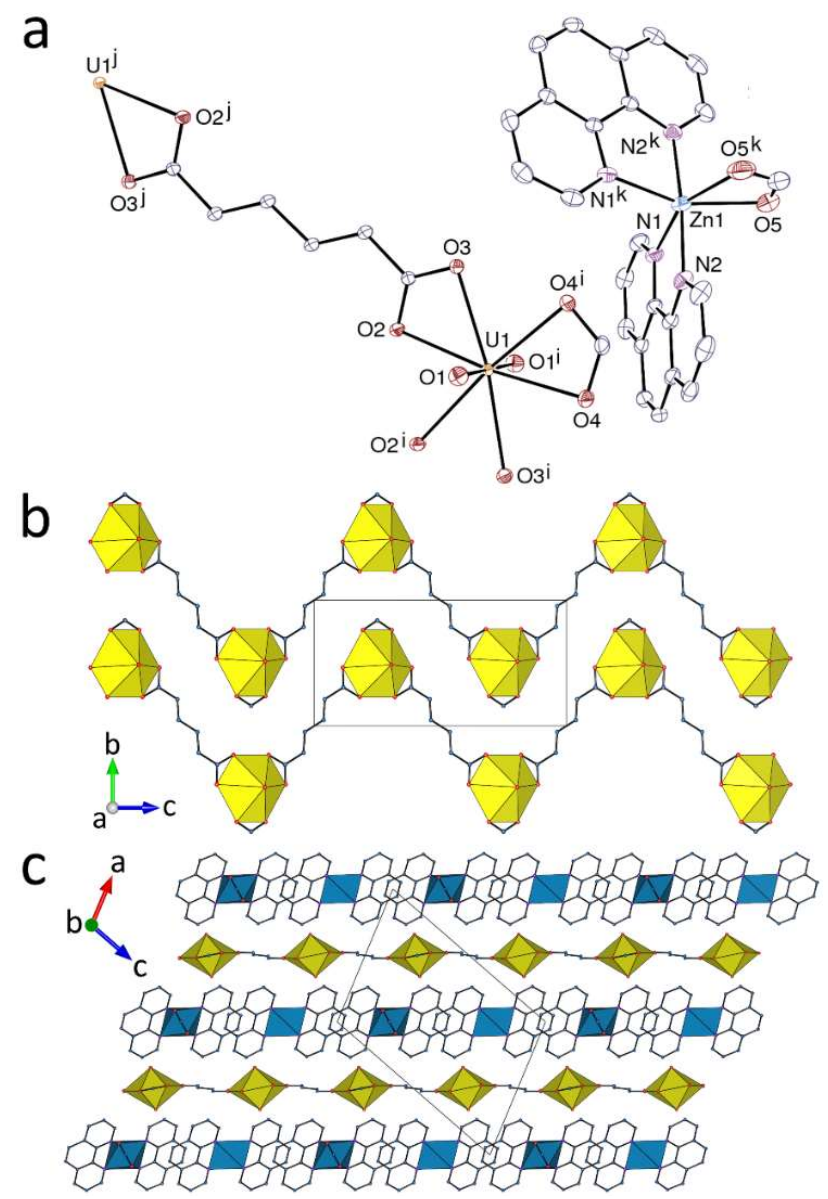

Fig. 1 (a) View of complex 1 with displacement ellipsoids shown at the $50 \%$ probability level. Symmetry codes: i $=1 / 2-x, y, 3 / 2-z ; \mathrm{j}=1-x, 2-y, 2-z ; \mathrm{k}=3 / 2-x, y, 3 / 2-z$. (b) View of two strands of the monoperiodic assembly. (c) Packing with chains viewed edge-on. Uranium coordination polyhedra are colored yellow and those of zinc(II) blue. Hydrogen atoms are omitted in all views.

also obtained with DMF as cosolvent and diverse combinations of metal cations and bipy or phen ligands (some of these complexes including oxo anions). ${ }^{39,53-56}$ Although none of the latter complexes involves $\mathrm{Zn}^{\mathrm{II}}$ cations, it seems difficult to rationalise this difference (see Table 2 for an overview of all these species). The synthesis of complex 1 provides an example of the preferential incorporation of formate derived from DMF hydrolysis rather than of its coproduct, dimethylammonium ion, which is more commonly found as a constituent of the crystals ultimately isolated from aqueous DMF. The uranyl cation in $\mathbf{1}$ is chelated in $\kappa^{2} O, O^{\prime}$ 
Table 2 Uranyl ion complexes with long-chain dicarboxylates and $M(\text { bipy/phen })_{2 / 3}{ }^{+/ 2+}$ cations

\begin{tabular}{|c|c|c|c|c|c|}
\hline compound & organic cosolvent & $\begin{array}{l}\text { "unexpected" } \\
\text { coligand }\end{array}$ & periodicity & geometry & ref \\
\hline$\left[\mathrm{UO}_{2} \mathrm{M}(\mathrm{C} 8)_{2}(\mathrm{phen})_{2}\right]_{2}(\mathrm{M}=\mathrm{Mn}, \mathrm{Co})$ & DMF & & 0 & tetranuclear complex & 53 \\
\hline$\left[\mathrm{M}(\text { bipy })_{3}\right]\left[\left(\mathrm{UO}_{2}\right)_{2}(\mathrm{C} 9)_{3}\right](\mathrm{M}=\mathrm{Co}, \mathrm{Ni})$ & DMF & & 0 & three-stranded helicate & 53 \\
\hline$\left[\mathrm{M}(\mathrm{phen})_{3}\right]\left[\left(\mathrm{UO}_{2}\right)_{2}(\mathrm{C} 12)_{3}\right](\mathrm{M}=\mathrm{Mn}, \mathrm{Co})$ & DMF & & 0 & three-stranded helicate & 53 \\
\hline$\left[\mathrm{Ni}\left(\mathrm{Me}_{4} \text { phen }\right)_{3}\right]_{2}\left[\left(\mathrm{UO}_{2}\right)_{4}(\mathrm{C} 7)_{3}\left(\mathrm{NO}_{3}\right)_{6}\right] \cdot \mathrm{CH}_{3} \mathrm{CN}$ & $\mathrm{CH}_{3} \mathrm{CN}$ & $\mathrm{NO}_{3}^{-}$ & 0 & tetranuclear complex & 39 \\
\hline$\left[\mathrm{Ag}(\text { bipy })_{2}\right]_{2}\left[\mathrm{UO}_{2}(\mathrm{C} 7)\left(\mathrm{NO}_{3}\right)\right]_{2}$ & $\mathrm{CH}_{3} \mathrm{CN}$ or $\mathrm{MeOH}$ & $\mathrm{NO}_{3}^{-}$ & 1 & linear or zigzag chain & 39,56 \\
\hline$\left[\mathrm{Fe}(\text { bipy })_{3}\right]\left[\left(\mathrm{UO}_{2}\right)_{2}(\mathrm{C} 7)_{3}\right] \cdot 3 \mathrm{H}_{2} \mathrm{O}$ & DMF & & 1 & ladder-like chain & 55 \\
\hline$\left[\mathrm{Cu}(\text { phen })_{2}\right]_{2}\left[\left(\mathrm{UO}_{2}\right)_{3}(\mathrm{C} 7)_{4}\left(\mathrm{H}_{2} \mathrm{O}\right)_{2}\right] \cdot 2 \mathrm{H}_{2} \mathrm{O}$ & DMF & & 1 & ladder-like chain & 55 \\
\hline$\left[\mathrm{Cu}(\text { bipy })_{2}\right]_{2}\left[\left(\mathrm{UO}_{2}\right)_{2}(\mathrm{C} 9)_{3}\right]$ & DMF & & 1 & ladder-like chain & 55 \\
\hline$\left[\mathrm{UO}_{2} \mathrm{Mn}(\mathrm{C} 13)_{2}(\text { bipy })_{2}\right]$ & DMF & & 1 & heterometallic chain & 54 \\
\hline$\left[\mathrm{UO}_{2} \mathrm{Mn}(\mathrm{C} 7)_{2}(\mathrm{phen})_{2}\right]$ & DMF & & 2 & heterometallic network & 39 \\
\hline$\left[\mathrm{M}(\text { phen })_{3}\right]\left[\left(\mathrm{UO}_{2}\right)_{3}(\mathrm{C} 8)_{3}(\mathrm{O})\right] \cdot \mathrm{H}_{2} \mathrm{O}(\mathrm{M}=\mathrm{Co}, \mathrm{Ni})$ & DMF & $\mathrm{O}^{2-}$ & 2 & furrowed network & 55 \\
\hline$\left[\mathrm{Co}(\text { phen })_{3}\right]\left[\left(\mathrm{UO}_{2}\right)_{3}(\mathrm{C} 9)_{3}(\mathrm{O})\right] \cdot \mathrm{H}_{2} \mathrm{O}$ & DMF & $\mathrm{O}^{2-}$ & 2 & furrowed network & 55 \\
\hline$\left[\mathrm{Ni}(\text { bipy })_{3}\right]\left[\left(\mathrm{UO}_{2}\right)_{2}(\mathrm{Cl0})_{3}\right] \cdot 2 \mathrm{H}_{2} \mathrm{O}$ & DMF & & 2 & network with decanuclear rings & 55 \\
\hline$\left[\mathrm{M}(\mathrm{phen})_{3}\right]\left[\left(\mathrm{UO}_{2}\right)_{2}(\mathrm{C} 10)_{3}\right] \cdot x \mathrm{H}_{2} \mathrm{O}(\mathrm{M}=\mathrm{Mn}, \mathrm{Co}, \mathrm{Ni})$ & DMF & & 2 & honeycomb network & 55 \\
\hline$\left[\mathrm{Ni}(\text { bipy })_{3}\right]\left[\left(\mathrm{UO}_{2}\right)_{2}(\mathrm{C} 12)_{3}\right]\left[\mathrm{UO}_{2}(\mathrm{C} 12)\left(\mathrm{H}_{2} \mathrm{O}\right)_{2}\right] \cdot \mathrm{H}_{2} \mathrm{O}$ & DMF & & $1 / 2$ & chain and honeycomb network & 55 \\
\hline$\left[\mathrm{Mn}(\mathrm{phen})_{3}\right]\left[\left(\mathrm{UO}_{2}\right)_{2}(\mathrm{C} 13)_{3}\right]$ & DMF & & 2 & entangled honeycomb networks & 54 \\
\hline$\left[\mathrm{Zn}(\mathrm{phen})_{2}(\mathrm{HCOO})\right]\left[\mathrm{UO}_{2}(\mathrm{muc})(\mathrm{HCOO})\right](\mathbf{1})$ & DMF & $\mathrm{HCOO}^{-}$ & 1 & zigzag chain & this work \\
\hline$\left[\mathrm{Ni}(\text { bipy })_{3}\right]\left[\left(\mathrm{UO}_{2}\right)_{2}(\mathrm{muc})_{3}\right] \cdot 5 \mathrm{H}_{2} \mathrm{O}$ & DMF & & 2 & honeycomb network & 52 \\
\hline
\end{tabular}

mode by three carboxylate groups from two $\mathrm{muc}^{2-}$ and one formate ligands, and the uranium atom, located on a twofold rotation axis, has a hexagonal-bipyramidal coordination environment [U-O(oxo), 1.7785(14) A; U-O(carboxylato), 2.4631(13)-2.4768(13) $\AA$ ]. Another formate anion acts also as a $\kappa^{2} O, O^{\prime}$ chelate on $\mathrm{Zn}^{\mathrm{II}}$, which is also chelated by two phen molecules, thus providing a complete, distorted octahedral coordination sphere and so ensuring that the coordination polymer formed is not heterometallic. Since the formate ligands do not bridge, the uranyl-containing coordination polymer is limited to a single stranded, monoperiodic form directed along [101]. The extended muconate ligand being essentially planar, these strands have a distinctly nearly planar, zigzag shape, and they lie side-by-side to give planar sheets parallel to (10ī). Each strand can be seen as part of the diperiodic, near-planar array known in the complex $\left[\mathrm{Ni}(\text { bipy })_{3}\right]\left[\left(\mathrm{UO}_{2}\right)_{2}(\text { muc })_{3}\right] \cdot 5 \mathrm{H}_{2} \mathrm{O}^{52}$ but in $\mathbf{1}$ the cations lie in sheets between those of the anions rather than within the same plane as in the latter complex. Part of the reason for greater segregation in complex 1 may be the larger size of the phen units 
compared to those of bipy, which appears to result in more obvious parallel-displaced $\pi$ stacking interactions between the cations [centroid...centroid distances, 3.4928(12) and 3.9011(12) $\AA$; dihedral angles, 1.06(10) and $0^{\circ}$; slippage 1.04 and $\left.2.02 \AA\right]$. These interactions are apparent on the Hirshfeld surface (HS) ${ }^{57}$ of the cation calculated with CrystalExplorer, ${ }^{58}$ but $\mathrm{CH} \cdots \mathrm{O}$ hydrogen bonds ${ }^{59}$ involving aromatic protons and oxygen atoms from both cation and anion are even more prominent $\left[\mathrm{C} \cdots \mathrm{O}, 3.229(2)-3.415(3) \AA \AA\right.$; $\left.\mathrm{C}-\mathrm{H} \cdots \mathrm{O}, 148-175^{\circ}\right]$, while $\left[\mathrm{Ni}(\text { bipy })_{3}\right]^{2+}$ can of course only be involved in $\mathrm{CH} \cdots \mathrm{O}$ interactions. The packing is compact and the Kitaigorodski packing index (KPI, evaluated with PLATON ${ }^{60}$ ) is 0.70 .

The complex $\left[\mathrm{UO}_{2}(\mathrm{muc})(\mathrm{NMP})\right](\mathbf{2})$, shown in Figure 2, provides an example of the apparent inhibition of acid ionisation to the extent required for formation of an anion of $\left[\left(\mathrm{UO}_{2}\right)_{2}(\text { acid dianion })_{3}\right]^{2-}$ composition in aqueous NMP, in the presence of $\mathrm{PPh}_{4}{ }^{+}$as a potential countercation. This is at variance with the ready incorporation of phosphonium cations in the structures of uranyl ion complexes with long-chain dicarboxylates previously reported, most of which being synthesized with DMF or no organic cosolvent (Table 3) ${ }^{52,61}$ It is particularly notable that the complex $\left[\mathrm{PPh}_{4}\right]_{2}\left[\left(\mathrm{UO}_{2}\right)_{2}(\mathrm{C} 6)_{3}\right]$ was obtained with NMP as cosolvent but, notwithstanding the closeness of $\mathrm{C}^{2-}$ and $\mathrm{muc}^{2-}$ ligands, NMP does not coordinate in this case. ${ }^{52}$ Complex $\mathbf{2}$ does not have the U/dicarboxylic acid stoichiometry of the reaction mixture designed to give rise to an anionic coordination polymer and its actual 1:1 U/dicarboxylate stoichiometry is that of a neutral species requiring no counter cation. That this is due to the resistance of the NMP solvent to hydrolysis and thus to any buffering at a higher $\mathrm{pH}$ than the initial value that can occur with DMF is indicated by the successful isolation of an anionic polymer from a mixture with the same 2:3 U:dicarboxylic acid ratio in complex 4 (see below) though this synthesis provides yet another example of the effectiveness of dimethylammonium 

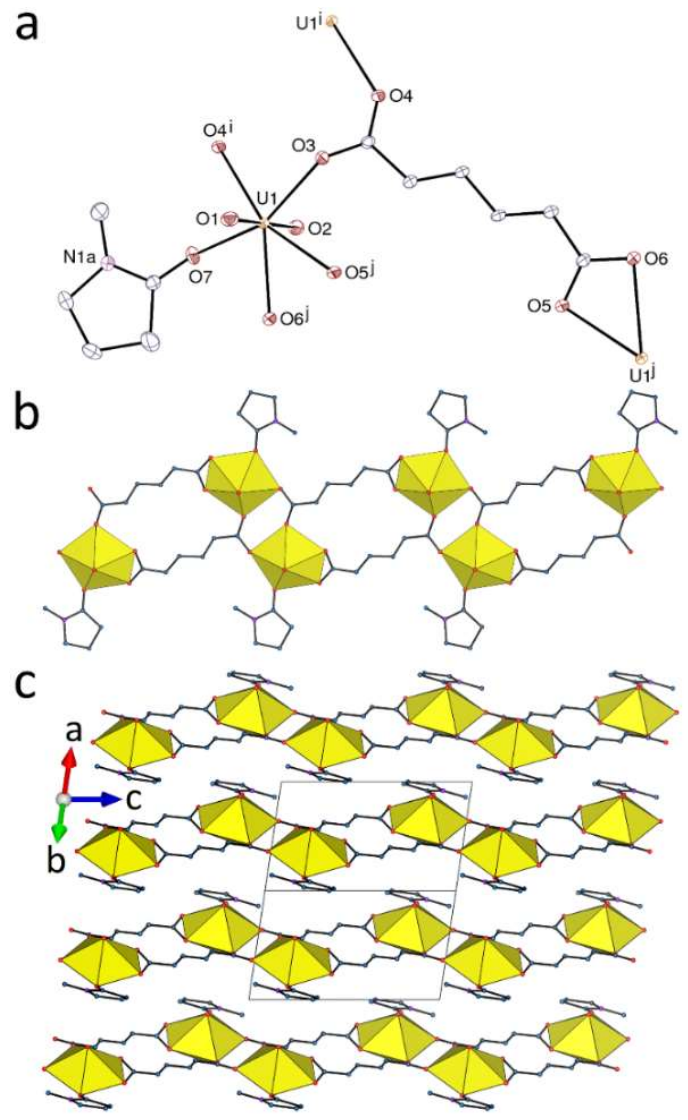

Fig. 2 (a) View of compound $\mathbf{2}$ with displacement ellipsoids shown at the 50\% probability level. Symmetry codes: $\mathrm{i}=1-x,-y,-z ; \mathrm{j}=1-x,-y, 1-z$. (b) View of the monoperiodic assembly. (c) Packing with ribbons viewed obliquely. Only one position of the disordered NMP molecule is represented and hydrogen atoms are omitted in all views.

Table 3 Uranyl ion complexes with long-chain dicarboxylates and $\mathrm{PPh}_{3} \mathrm{Me}^{+}$or $\mathrm{PPh}_{4}^{+}$ counterions

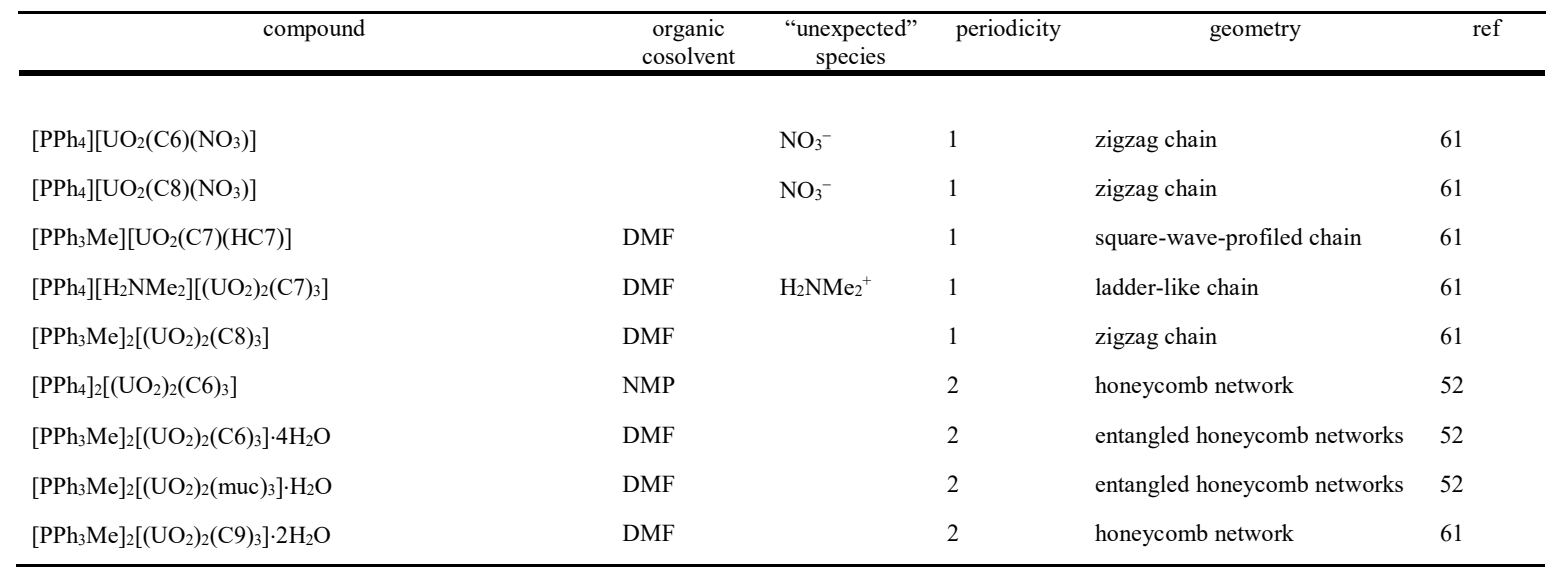


ion in crystallising such a polymer, thus leaving the alternative counter-cation, $\left[\mathrm{Co}(\mathrm{en})_{3}\right]^{3+}$, in solution. Complex 2 contrasts also with that obtained from reaction in aqueous DMF with $\mathrm{PPh}_{3} \mathrm{Me}^{+}$in place of $\mathrm{PPh}_{4}{ }^{+}$, which yields $\left[\mathrm{PPh}_{3} \mathrm{Me}\right]_{2}\left[\left(\mathrm{UO}_{2}\right)_{2}(\mathrm{muc})_{3}\right] \cdot \mathrm{H}_{2} \mathrm{O}$, a species displaying twofold inclined polycatenation of networks with hcb topology. ${ }^{52}$ The obvious reasons for this difference are that it arises both from the increase in $\mathrm{pH}$ that must result from the hydrolysis of DMF to dimethylammonium formate, and from the strong coordinating power of NMP, which is most often coordinated to the uranyl ion when used as a cosolvent, ${ }^{62}$ and, in the present case (but not as a general rule), limits the periodicity of the polymer. The uranyl cation in $\mathbf{2}$ is $\kappa^{2} O, O^{\prime}-$ chelated by one carboxylate group and bound to three more oxygen donors from two muc ${ }^{2-}$ ligands and one NMP molecule, the uranium atom environment being thus pentagonalbipyramidal [U-O(oxo), 1.7729(15) and 1.7745(15) $\AA$; U-O(carboxylato), 2.4266(15) and 2.4820(15) $\AA$ for the chelating group, 2.3412(14) and 2.4217(14) $\AA$ for the others; U-O(NMP), $2.3029(15) \AA]$. The muc ${ }^{2-}$ ligand connects three metal cations, one in the $\kappa^{2} O, O^{\prime}$ mode and the other two in the bridging, syn/anti $\mu_{2}-\kappa^{1} O: \kappa^{1} O^{\prime}$ mode. Due to the terminal nature of the NMP ligand, the coordination polymer formed is monoperiodic only, and it has the shape of a quasiplanar ribbon directed along [001]. Here also, the HS reveals the presence of $\mathrm{CH} \cdots \mathrm{O}$ hydrogen bonds, involving in particular the protons of the NMP molecules, and the packing is compact (KPI, 0.72 with disorder excluded).

Also with NMP as cosolvent, but with $\left[\mathrm{Co}(\mathrm{en})_{3}\right]^{3+}$ as possible counterion instead of $\mathrm{PPh}_{4}{ }^{+}$, octanedioic acid $\mathrm{H}_{2} \mathrm{C} 8$ gives a complex similar to 2, $\left[\mathrm{UO}_{2}(\mathrm{C} 8)(\mathrm{NMP})\right](3)$. This result is at variance with that obtained with $\mathrm{C}^{2-}$, the same trication and $\mathrm{CH}_{3} \mathrm{CN}$ as cosolvent, which results in a mixture of $\left[\mathrm{NH}_{4}\right]_{2}\left[\left(\mathrm{UO}_{2}\right)_{2}(\mathrm{C} 7)_{3}\right] \cdot 2 \mathrm{H}_{2} \mathrm{O}$, displaying $2 \mathrm{D} \rightarrow 3 \mathrm{D}$ parallel polycatenation, and $\left[\mathrm{Co}(\mathrm{en})_{3}\right]_{2}\left[\left(\mathrm{UO}_{2}\right)_{12}(\mathrm{C} 7)_{7}(\mathrm{O})_{4}(\mathrm{OH})_{8}\right] \cdot 2 \mathrm{CH}_{3} \mathrm{CN} \cdot 3 \mathrm{H}_{2} \mathrm{O}$, a triperiodic framework. ${ }^{39}$ The last two compounds are in themselves an illustration of the formation of different unexpected components in the same experiment, ammonium cations from acetonitrile 
hydrolysis, and oxo/hydroxo anions, the intended counterion $\left[\mathrm{Co}(\mathrm{en})_{3}\right]^{3+}$ being included in only one case, while complex $\mathbf{3}$ shows that a more strongly coordinating solvent results in complete exclusion of this cation. The uranium coordination environment is identical [U-O(oxo),

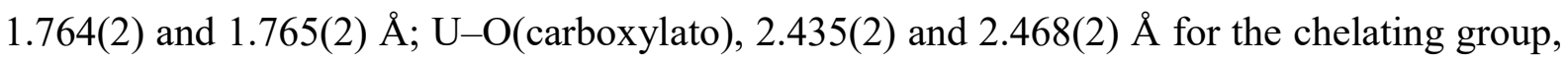
2.318(2) and 2.368(2) $\AA$ for the others; U-O(NMP), 2.343(2) $\AA$ ], as well as the connectivity of the dicarboxylate ligand (Figure 3). The monoperiodic coordination polymer is here directed

a

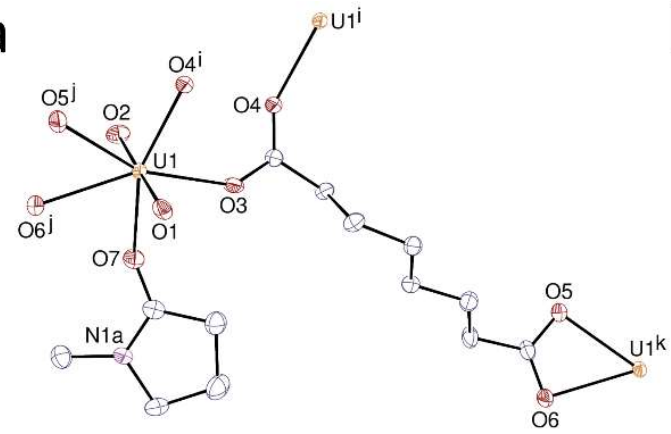

$\mathrm{C}$

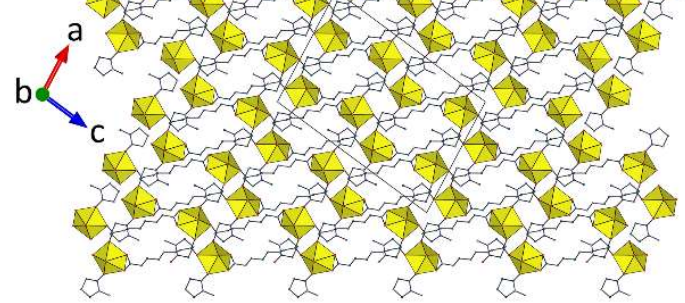

b

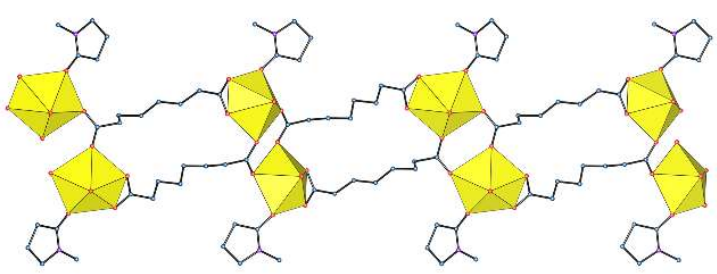

d

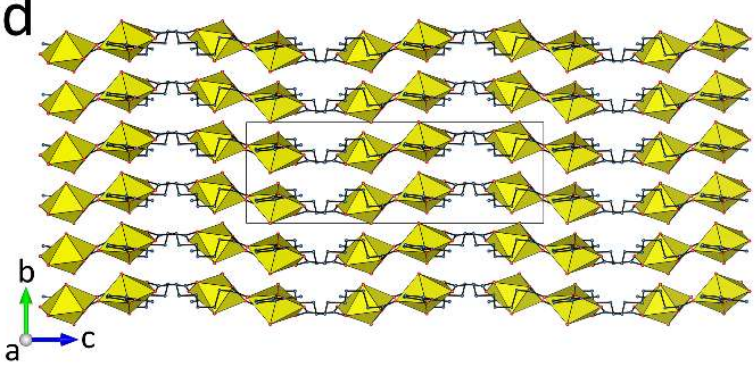

Fig. 3 (a) View of compound $\mathbf{3}$ with displacement ellipsoids shown at the $50 \%$ probability level. Symmetry codes: $\mathrm{i}=1 / 2-x, 3 / 2-y, 1-z ; \mathrm{j}=x-1 / 2,3 / 2-y, z-1 / 2 ; \mathrm{k}=x+1 / 2,3 / 2-y, z+1 / 2$. (b) View of the monoperiodic assembly. (c) and (d) Two views of the packing. Only one position of the disordered NMP molecule is represented and hydrogen atoms are omitted in all views.

along [101] and it is only slighly undulating in spite of the flexibility of the $\mathrm{C} 8^{2-}$ ligand which adopts a conformation somewhat distorted with respect to that of the regularly extended form. The packing is close to that found in 2 (KPI, 0.69 with disorder excluded). The first investigations ${ }^{63,64}$ of $\mathrm{C}^{2-}$ complexes of uranyl ion were conducted under purely hydrothermal conditions employing a 1:1 molar ratio of the acid $\mathrm{H}_{2} \mathrm{C} 8$ and uranyl nitrate. Under exactly these 
conditions, ${ }^{63}$ the crystalline product was an anhydrous, neutral diperiodic polymer of composition $\left[\mathrm{UO}_{2}(\mathrm{C} 8)\right]$ where both carboxylate groups of the ligand were involved in bridgingchelation bonding to give $\mathrm{U}^{\mathrm{VI}}$ centres of hexagonal-bipyramidal coordination geometry. While the stoichiometry of the solid was that of the reaction mixture, a better yield was obtained by doubling the original amount of acid. A change in conditions involving the addition of ammonia to raise the initial $\mathrm{pH}$ of the reaction mixture to a value $\sim 3.5$ and of either 4,4 '-bipyridine or $1,2-$ bis(4-pyridyl)ethane, provided quite different products involving tetranuclear, bis( $\mu_{3}$-oxobridged) uranium units, seemingly a reflection of the more basic nature of the reaction medium, with the pyridine ligands directly bound to uranium. ${ }^{64}$ A very similar tetranuclear species was found during later work ${ }^{15}$ in which cucurbit[6]urils were added to the reaction mixture, though the use of aqueous DMF as the reaction solvent resulted in a structure containing dimethylammonium cation as well as cucurbit[6]uril. Further addition here of $\mathrm{Sr}^{\mathrm{II}}$ resulted in detachment of the cucurbituril from uranium (though with the $\mathrm{Sr}^{\mathrm{II}}$ cucurbituril complex incorporated in the structure) and a diperiodic $\mathrm{UO}_{2}-\mathrm{C} 8$ polymer being formed in which tetranuclear units involving pentagonal-bipyramidal $\mathrm{U}^{\mathrm{VI}}$ were accompanied by diuranacyclic entities involving hexagonal-bipyramidal $\mathrm{U}^{\mathrm{VI}}$, the dimethylammonium cation being absent. Similar diuranacyclic units were seen in a contemporaneous extension ${ }^{65}$ of the original hydrothermal syntheses where 1,2-bis(4-pyridyl)ethene was included in a 1:1 $\mathrm{U}: \mathrm{H}_{2} \mathrm{C} 8$ mixture adjusted to $\mathrm{pH} \sim 3.5$. Here, unlike the earlier known structures, there was no evidence of uranyl ion hydrolysis, with the diprotonated 1,2-bis(4-pyridyl)ethene accompanying a monoperiodic, catenary (linked uranacycles) polymer of $2: 3 \mathrm{U}: \mathrm{C} 8^{2-}$ composition. The diuranacyclic unit alone, its extension blocked by $\mathrm{M}(\mathrm{phen})_{2}$ units $\left(\mathrm{M}=\mathrm{Co}^{\mathrm{II}}\right.$ or $\left.\mathrm{Mn}^{\mathrm{II}}\right)$ coordinated to the terminus of two of the four $\mathrm{C}^{2-}$ ligands, appeared in complexes prepared in aqueous $\mathrm{DMF},{ }^{53}$ although from the same reaction mixture it also proved possible ${ }^{55}$ to crystallise a diperiodic anionic polymer accompanied by $\left[\mathrm{M}(\text { phen })_{3}\right]^{2+}$ cations $\left(\mathrm{M}=\mathrm{Co}^{\mathrm{II}}\right.$ or $\left.\mathrm{Ni}^{\mathrm{II}}\right)$ in which both tetranuclear, bis $\left(\mu_{3}-\mathrm{oxo}-\right.$ 
bridged) units with $\mathrm{U}^{\mathrm{VI}}$ in pentagonal-bipyramidal coordination and mononuclear units with $\mathrm{U}^{\mathrm{VI}}$ in hexagonal-bipyramidal coordination were present. The simplest coordination polymer known involving this ligand was obtained ${ }^{23}$ by the use of the 2,2'-bipyridine (bipy) ligand, suited to chelation rather than to bridging as with 4,4'-bipyridine and 1,2-bis(4-pyridyl)ethane. ${ }^{64}$ From aqueous DMF solvent, the crystals of $\left[\mathrm{UO}_{2}\right.$ (bipy)(C8)] obtained have a structure involving a monoperiodic, helical polymer with $\mathrm{U}^{\mathrm{VI}}$ in hexagonal-bipyramidal $\mathrm{O}_{6} \mathrm{~N}_{2}$ coordination. Obtained by hydrothermal synthesis, ${ }^{61}$ a similar polymer also appears in $\left[\mathrm{PPh}_{4}\right]\left[\mathrm{UO}_{2}(\mathrm{C} 8)\left(\mathrm{NO}_{3}\right)\right]$, where chelating nitrate replaces chelating bipy, but solvothermal (aqueous DMF) synthesis with $\mathrm{PPh}_{3} \mathrm{Me}^{+}$in place of $\mathrm{PPh}_{4}{ }^{+}$in the reaction mixture generated crystals of composition $\left[\mathrm{PPh}_{3} \mathrm{Me}\right]_{2}\left[\left(\mathrm{UO}_{2}\right)_{2}(\mathrm{C} 8)_{3}\right]$ containing a monoperiodic polymer with diuranacyclic units linked by $\mathrm{C} 8^{2-}$ bridges as in the complex obtained hydrothermally involving the diprotonated 1,2-bis(4-pyridyl)ethene cation. It is this remarkable variety in the behaviour of a rather simple ligand which prompted our efforts to further investigate possible countercation influences, hence the synthesis of $\mathbf{3}$ in the presence of $\left[\mathrm{Co}(\mathrm{en})_{3}\right] \mathrm{Cl}_{3}$. The structure of $\mathbf{3}$ is quite unlike that of the unsolvated material. ${ }^{63}$ The use of NMP is significant, not simply because it appears in the product and is an hydrolysis-resistant amide but also because even when it is not found in the product its effect on product solubility can be very different to that of the DMF used in many of the syntheses described above. ${ }^{61}$ There is also a difference in the syntheses of $\left[\mathrm{UO}_{2}(\mathrm{C} 8)\right]$ and $\left[\mathrm{UO}_{2}(\mathrm{C} 8)(\mathrm{NMP})\right]$ in that the ratio $\mathrm{U}: \mathrm{H}_{2} \mathrm{C} 8$ in the latter was designed to favour the formation of an anionic complex $\left[\left(\mathrm{UO}_{2}\right)_{2}(\mathrm{C} 8)_{3}\right]^{2-}$, although there is ample evidence that reactant ratios do not always determine that of the product. Thus, the most that can be said here is that the solubility of any associate of $\left[\mathrm{Co}(\mathrm{en})_{3}\right]^{3+}$ with a uraniumcontaining anion was not exceeded under the conditions applied. Strong hydration of $\left[\mathrm{Co}(\mathrm{en})_{3}\right]^{3+}$ may explain the high aqueous solubility of many of its salts and why it is less effective in crystallising anionic uranyl derivatives than relatively hydrophobic cations such as 
$\left[\mathrm{M}(\mathrm{phen})_{3}\right]^{2+}(\mathrm{M}=$ transition metal $)$ species even though the latter are capable only of weak $\mathrm{CH} \cdots \mathrm{O}$ interactions in the solids.

The complex $\left[\mathrm{H}_{2} \mathrm{NMe}_{2}\right]_{2}\left[\left(\mathrm{UO}_{2}\right)_{2}(\mathrm{C} 13)_{3}\right](4)$ provides yet another example of a species which crystallises as a result of the presence of dimethylammonium cation produced by hydrolysis of DMF and also, after 3 and $\left[\mathrm{NH}_{4}\right]_{2}\left[\left(\mathrm{UO}_{2}\right)_{2}(\mathrm{C} 7)_{3}\right] \cdot 2 \mathrm{H}_{2} \mathrm{O},{ }^{39}$ a case in which the $\left[\mathrm{Co}(\mathrm{en})_{3}\right]^{3+}$ cation is excluded from the crystallised product. The crystal structure of 4 is isomorphous to that of $\left[\mathrm{H}_{2} \mathrm{NMe}_{2}\right]_{2}\left[\left(\mathrm{UO}_{2}\right)_{2}(\mathrm{C} 15)_{3}\right]$, where $\mathrm{C} 15^{2-}$ is the dianion of $1,15-$ pentadecanedioic acid, the metal complex involving the longest $\alpha, \omega$-aliphatic dicarboxylate ligand crystallographically characterised, ${ }^{29 i}$ and it thus provides an example of where increasing chain length does not seem to have a significant effect (provided of course that the parity of the number of carbon atoms is unchanged). The uranium centre, which is $\operatorname{tris}\left(\kappa^{2} O, O^{\prime}\right)$-chelated by three different $\mathrm{C} 13^{2-}$ ligands [U-O(oxo), 1.770(4) and 1.772(4) $\AA$; U-O(carboxylato), 2.437(4)-2.492(4) $\AA$ ], is a 3-coordinated (3-c) node, and the two ligands, one of them with twofold rotation symmetry, are bis(chelating) and thus simple links in the coordination polymer formed (Figure 4). Although the ratio U:carboxylate in the crystals is $1: 3$ and thus might be expected $^{52}$ to produce a diperiodic polymer with hcb topology, the diperiodic polymer actually present, parallel to (201), has the vertex symbol $\left\{8^{2} .10\right\}$ and the KIa topological type, also found in a uranyl complex with glutarate. ${ }^{64}$ As in the $\mathrm{C} 15^{2-}$ complex, the ligand with twofold rotation symmetry is in the all-trans conformation and nearly planar while the other is kinked at one end. The sheets have a distinctly bilayer form, well apparent when viewed down [102] (Figure 4c), with two, upper and lower rows of monoperiodic chains linked to one another by the ligands with twofold rotation symmetry. These polymers are chiral, and the chirality alternates from one sheet to the next. The dimethylammonium counterions form intralayer hydrogen bonds 


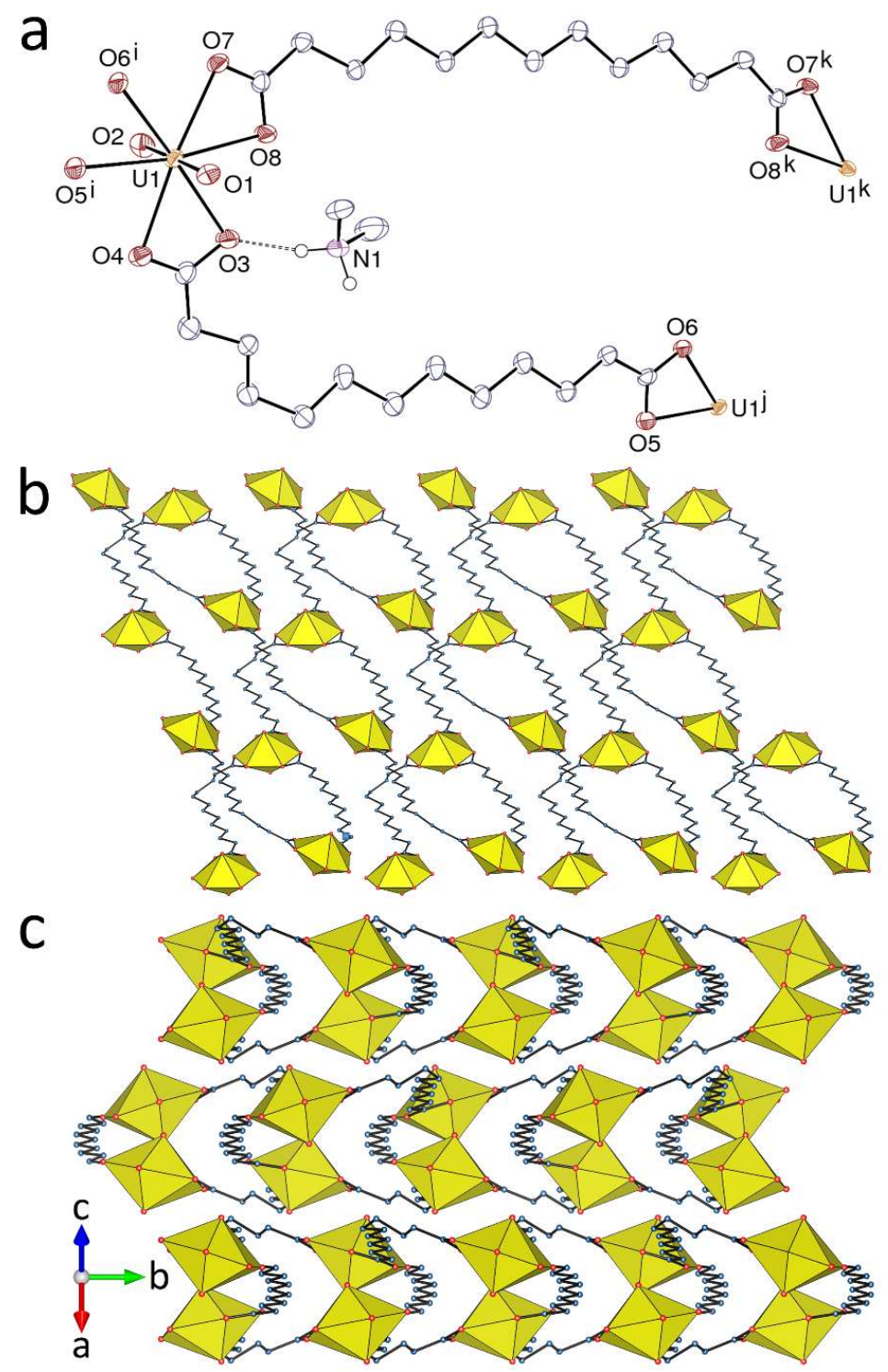

Fig. 4 (a) View of compound 4 with displacement ellipsoids shown at the $50 \%$ probability level. Carbon-bound hydrogen atoms are omitted and the hydrogen bond is shown as a dashed line. Symmetry codes: $\mathrm{i}=x+1 / 2, y+$ $1 / 2, z+1 ; j=x-1 / 2, y-1 / 2, z-1 ; k=1-x, y, 1 / 2-z$. (b) View of the diperiodic assembly. (c) Packing with bilayer sheets viewed edge-on.

(one of them possibly bifurcated) with three carboxylate oxygen atoms $[\mathrm{N} \cdots \mathrm{O}, 2.811(6)-$ 2.914(7) $\left.\AA ; \mathrm{N}-\mathrm{H} \cdots \mathrm{O}, 113-164^{\circ}\right]$. As in the $\mathrm{C} 15^{2-}$ complex, the KPI is somewhat low $(0.59)$, indicating the presence of disordered solvent molecules, whose contribution to the structure factors has been subtracted with the SQUEEZE software (see Experimental). While a uranyl ion complex with $\mathrm{C} 15^{2-}$ was only obtained in the presence of $\mathrm{H}_{2} \mathrm{NMe}^{2+}$, thus preventing a 
discussion of the effect of different counterions on the structure, in the case of the $\mathrm{C} 13^{2-}$ heterometallic mono- and diperiodic polymers involving association with $\left[\mathrm{Mn}(\mathrm{bipy})_{2}\right]^{2+}$ or $\left[\mathrm{Mn}(\text { phen })_{3}\right]^{2+}$ units, respectively, the latter exhibiting Borromean entanglement, have been structurally characterised. ${ }^{54}$ One of the remarkable features of the coordination chemistry of uranyl ion with aliphatic $\alpha, \omega$-dicarboxylates is the sensitivity of the structures to changes in the chain length, this being well illustrated by comparison of species having the same U:dicarboxylate ratio of $2: 3$ for $\mathrm{C}_{12} 2^{-}$and $\mathrm{C}^{2-} 3^{2-}$ where the former involves binuclear helicates ${ }^{53}$ and the latter an interpenetrated diperiodic polymer. There are, nonetheless, rather few structures known for uranyl ion complexes of $\mathrm{C}_{13} 3^{2-}$ and aspects of their syntheses are somewhat obscure. Thus, reaction mixtures with a $\mathrm{U}: \mathrm{H}_{2} \mathrm{C} 13$ ratio near $2: 3$ in aqueous NMP containing also $\mathrm{Mn}^{\mathrm{II}}$ and bipy or phen provided (under solvo-hydrothermal conditions) just monoperiodic polymers of $1: 1$ composition $\left[\mathrm{UO}_{2}(\mathrm{C} 13)\left(\right.\right.$ bipy/phen)] with no $\mathrm{Mn}^{\mathrm{II}}$ incorporation, while similar mixtures in aqueous DMF provided (again solvo-hydrothermally) $\left[\mathrm{Mn}(\mathrm{phen})_{3}\right]\left[\left(\mathrm{UO}_{2}\right)_{2}(\mathrm{C} 13)_{3}\right]$ (the species showing Borromean interpenetration) and $\left.\left[\mathrm{UO}_{2} \mathrm{Mn}(\mathrm{C} 13)_{2} \text { (bipy) }\right)_{2}\right]$, the latter being a true heterometallic monoperiodic polymer. In the present study where $\left[\mathrm{Co}(\mathrm{en})_{3}\right]^{3+}$ has been substituted for $\mathrm{Mn}^{\mathrm{II}}$-bipy/phen in aqueous $\mathrm{DMF}$, this substitution has resulted in the isolation of a material which presumably could also have been obtained from the mixtures containing $\mathrm{Mn}^{\mathrm{II}}$ and bipy or phen, indicating that it must be more soluble than either $\left[\mathrm{Mn}(\text { phen })_{3}\right]\left[\left(\mathrm{UO}_{2}\right)_{2}(\mathrm{C} 13)_{3}\right]$ or $\left[\mathrm{UO}_{2} \mathrm{Mn}(\mathrm{C} 13)_{2}(\text { bipy })_{2}\right]$. The possibility that $\left[\mathrm{Co}(\mathrm{en})_{3}\right]^{3+}$ may have accelerated the hydrolysis of DMF is discounted given instances where dimethylammonium cation is generated rapidly in media where uranyl ion is the only cation present, so that again it appears simply that solubility is the reason for the limited utility of $\left[\mathrm{Co}(\mathrm{en})_{3}\right]^{3+}$ as an agent for crystallisation. 


\section{Luminescence properties}

The emission spectra of complexes 1, 2 and $\mathbf{4}$ in the solid state were measured at room temperature under excitation at a wavelength of $420 \mathrm{~nm}$ and they are shown in Figure 5.

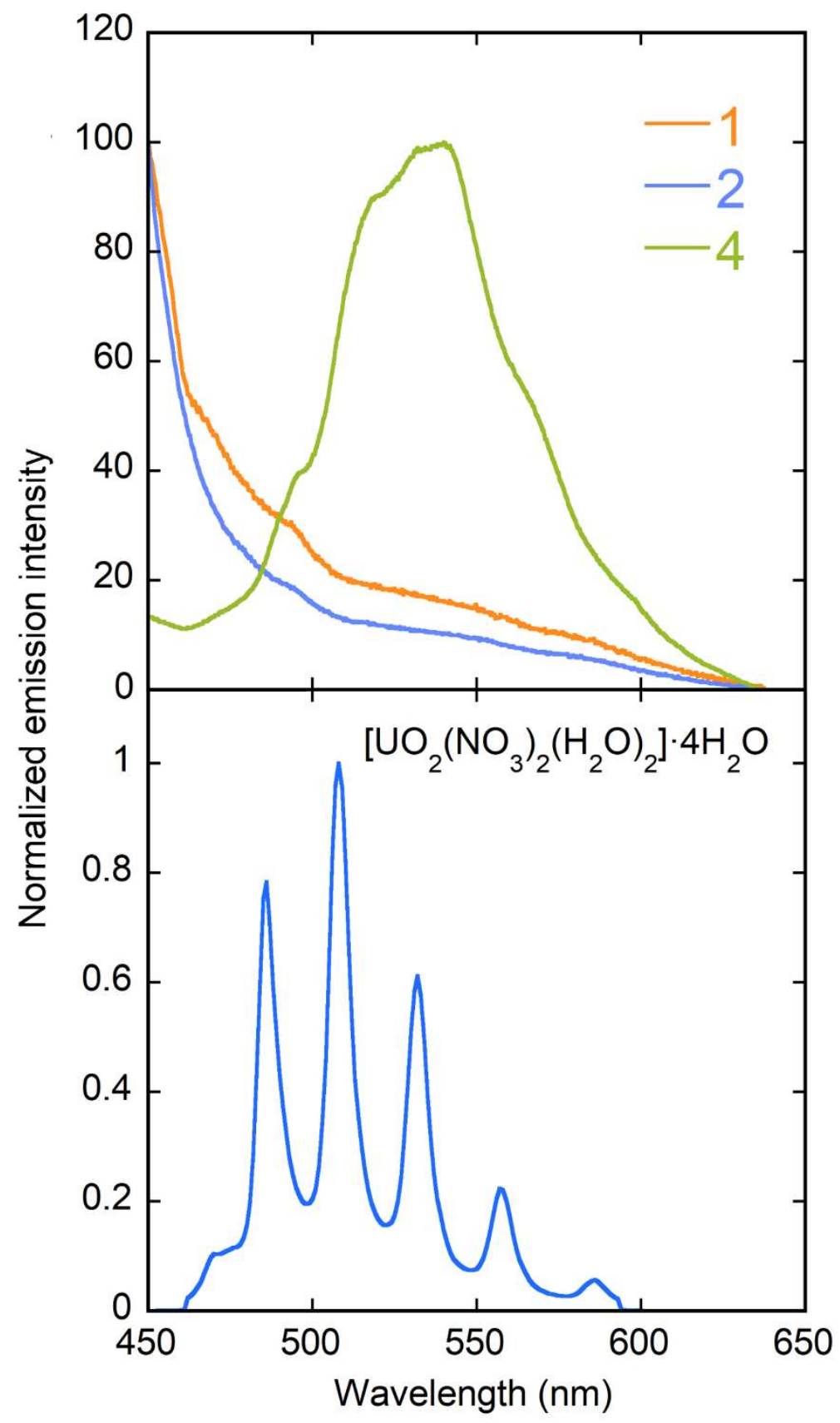

Fig. 5 Top: Emission spectra of complexes 1, $\mathbf{2}$ and $\mathbf{4}$ in the solid state at room temperature, under excitation at a wavelength of $420 \mathrm{~nm}$. Bottom: Emission spectrum of uranyl nitrate hexahydrate under the same conditions. 
Complexes $\mathbf{1}$ and $\mathbf{2}$ appear to be non-emissive, with a photoluminescence quantum yield (PLQY) lower than $1 \%$. While $420 \mathrm{~nm}$ is a region where uranyl ion absorbs, the absorptivity is low and in complexes $\mathbf{1}$ and $\mathbf{2}$, strong absorptions by muconate or phenanthroline overlap this region, so that ligand absorption without energy transfer to uranyl ion may explain the lack of uranyl emission. Instead of displaying the well-resolved vibronic fine structure often observed for emissive uranyl ion complexes, ${ }^{66}$ as in the spectrum of uranyl nitrate hexahydrate shown for comparison in Figure 5, the spectrum of 4 shows only a broad, unresolved peak in the $\sim 470$ $600 \mathrm{~nm}$ range, with a maximum at $540 \mathrm{~nm}$. An indication of the fine structure is given by shoulders arising from the probable presence of five convoluted peaks. Although the range is that which is usual, precise location of the vibronic peaks is not possible. At $4 \%$, the PLQY of 4 is low, and it is notable that the isomorphous $\mathrm{C} 15^{2-}$ complex, although its PLQY has not been measured, has a well-resolved but similarly weak emission spectrum.

\section{Conclusions}

The present work illustrates some of the considerations which should precede the application of solvothermal procedures to the synthesis of uranyl ion carboxylate complexes, defined through structural characterisation of four complexes with ligands in the family of long-chain saturated or unsaturated aliphatic dicarboxylates, muconate, 1,8-octanedioate and 1,13tridecanedioate. Co-solvent hydrolysis, found here in the case of DMF in the synthesis of complexes 1 and 4, is of course of general significance and could well be of greater use if viewed as a variant of the "homogeneous precipitation" method. ${ }^{67}$ While not discussed above, we have found acetonitrile hydrolysis to be a useful method of generating ammonium ion in situ. $^{29 d, h, 38,68}$ Solvent complexation is also a frequent perturbing factor, often resulting in periodicity limitation, as shown here by complexes $\mathbf{2}$ and $\mathbf{3}$, although its effects are not necessarily negative in this respect. ${ }^{62}$ It is unsurprising to see that acidic uranyl nitrate solutions 
exposed to light are oxidising but, given that solvothermal reactions are conducted in pressurised vessels, they are not without danger and one reason we have not employed dimethylsulfoxide as a co-solvent is because initial experiments showed that it could lead to violent explosions. It has also been our experience that ligands such as the amino acids are unsuited to reaction with uranyl ion under solvothermal conditions since their use results in rapid and complete decomposition. Aside from such practical concerns, it is apparent that limitation to the structural characterisation of the crystalline products of solvothermal processes leaves a great deal of hidden chemistry to be further explored. The fact that, for example, in solvothermal syntheses using aqueous DMF as the solvent it is possible to obtain products incorporating intact DMF as well as products containing its hydrolysis products, ${ }^{69}$ could be interpreted as meaning that there is a uranyl-ion-catalysed equilibrium established between these components but at present this can be neither confirmed nor denied. Oxalate production from an organic zwitterionic dicarboxylate has recently been shown to be $\mathrm{pH}$-dependent ${ }^{70}$ but further details of the chemistry involved, as in numerous other cases, ${ }^{25 c, d}$ are still lacking. Notwithstanding all the uncertainties associated with the use of solvothermal methods of synthesis, examination of the compounds reported in Tables 2 and 3, for example, shows that in the vast majority of cases, the crystallised product effectively contains the expected components, so that this synthetic method remains the most reliable and the most used for the design of coordination polymers.

\section{Conflicts of interest}

There are no conflicts of interest to declare.

\section{References}

1. R. Taylor and P. A. Wood, Chem. Rev., 2019, 119, 9427. 
2. (a) G. Demazeau, J. Mater. Chem., 1999, 9, 15; (b) G. Demazeau, J. Mater. Chem., 2008, 43, 2104; (c) G. Demazeau, Z. Naturforsch., 2010, 65b, 999.

3. D. Sud and G. Kaur, Polyhedron, 2021, 193, 114897.

4. K. Lv, S. Fichter, M. Gu, J. März and M. Schmidt, Coord. Chem. Rev., 2021, 446, 214011.

5. C. A. Stackhouse and S. Ma, Polyhedron, 2018, 145, 154.

6. H. He, L. Hashemi, M. L. Hu and A. Morsali, Coord. Chem. Rev., 2018, 376, 319.

7. L. W. Jin, Q. Liu and W. Y. Sun, CrystEngComm, 2014, 16, 3816.

8. W. Lin, W. N. Rieter and K. M. L. Taylor, Angew. Chem. Int. Ed., 2009, 48, 650.

9. C. D. Alcorn, J. S. Cox, L. M. S. G. A. Applegarth and P. R. Tremaine, J. Phys. Chem. B, 2019, 126, 7385 .

10. P. Zanonato, P. D. Bernardo, A. Bismondo, G. Liu, X. Chen and L. Rao, J. Am. Chem. Soc., 2004, 126, 5515.

11. D. A. Buckingham, J. M. Harrowfield and A. M. Sargeson, J. Am. Chem. Soc., 1974, 96, 1726

12. P. Thuéry and J. Harrowfield, Eur. J. Inorg. Chem., 2021, 3699.

13. J. F. Qian, W. J. Tian, S. Yang, Z. H. Sun, L. Chen, M. J. Wei, Z. Wu, M. Y. He, Z. H. Zhang and L. Mei, Inorg. Chem., 2020, 59, 17659.

14. I. Mihalcea, C. Falaise, C. Volkringer, N. Henry and T. Loiseau, Inorg. Chem. Commun., 2014, 44, 63.

15. P. Thuéry, Cryst. Growth Des., 2011, 11, 2606.

16. T. J. Mooibroek, P. Gamez, A. Pevec, M. Kasunic, B. Kozlevcar, W. T. Fu and J. Reedijk, Dalton Trans., 2010, 39, 6483.

17. X. Y. Wang, L. Gan, S. W. Zhang and S. Gao, Inorg. Chem., 2004, 43, 4615.

18. P. Thuéry and J. Harrowfield, CrystEngComm, 2021, 23, 7305.

19. L. A. Borkowski and C. L. Cahill, Inorg. Chem., 2003, 42, 7041. 
20. M. Kalaj and S. M. Cohen, ACS Cent. Sci., 2020, 6, 1046.

21. R. Haldar and C. Wöll, NanoResearch, 2021, 14, 355.

22. P. Mahata, M. Prabu and S. Natarajan, Inorg. Chem., 2008, 47, 8451.

23. P. Thuéry and J. M. Harrowfield, CrystEngComm, 2016, 18, 3905.

24. (a) B. T. McGrail, L. S. Pianowski and P. C. Burns, J. Am. Chem. Soc., 2014, 136, 4797;

(b) S. G. Thangavelu and C. L.Cahill, Inorg. Chem., 2015, 54, 4208.

25. (a) M. B. Andrews and C. L. Cahill, CrystEngComm, 2011, 13, 7068; (b) K. E. Knope, H. Kimura, Y. Yasaka, M. Nakahara, M. B. Andrews and C. L. Cahill, Inorg. Chem., 2012, 51, 3883; (c) P. Thuéry and J. M. Harrowfield, Inorg. Chem., 2015, 54, 8093 and references therein; (d) P. Thuéry, Y. Atoini and J. Harrowfield, Cryst. Growth Des., 2018, 18, 3167.

26. (a) S. J. Formosinho, H. D. Burrows, M. da G. Miguel, M. E. D. G. Azenha, I. M. Saraiva, A. C. D. N. Ribeiro, I. G. Khudyakov, R. G. Gasanov, M. Bolte and M. Sarakha, Photochem. Photobiol. Sci., 2003, 2, 569; (b) H. D. Burrows and M. da G. Miguel, Adv. Collod Interf. Sci., 2001, 89-90, 485.

27. Y. Li, J. Su, E. Mitchell, G. Q. Zhang and J. Li, Sci. China Chem., 2013, 56, 1671.

28. P. Thuéry and J. Harrowfield, Eur. J. Inorg. Chem., 2021, 2182.

29. (a) P. Thuéry and J. Harrowfield, Inorg. Chem., 2021, 60, 9074; (b) P. Thuéry and J. Harrowfield, Cryst. Growth Des., 2021, 21, 3000; (c) Y. Atoini, J. Harrowfield, Y. Kim and P. Thuéry, J. Incl. Phenom. Macrocyclic Chem., 2021, 100, 89; (d) P. Thuéry, Y. Atoini, S. Kusumoto, S. Hayami, Y. Kim and J. Harrowfield, Eur. J. Inorg Chem., 2020, 4391; (e) P. Thuéry, Y. Atoini and J. Harrowfield, Inorg. Chem., 2020, 59, 2923; (f) P. Thuéry, Y. Atoini and J. Harrowfield, Dalton Trans., 2020, 49, 817; (g) P. Thuéry, Y. Atoini and J. Harrowfield, Inorg. Chem., 2020, 59, 2503; (h) P. Thuéry and J. Harrowfield, Cryst. Growth Des., 2020, 20, 262; (i) P. Thuéry and J. Harrowfield, Dalton Trans., 2017, 46, 13677; (j) P. Thuéry and J. Harrowfield, Polyhedron, 2015, 98, 5; (k) P. Thuéry and J. Harrowfield, 
CrystEngComm, 2015, 17, 4006; (l) P. Thuéry, E. Rivière and J. Harrowfield, Inorg. Chem., 2015, 54, 2838; (m) P. Thuéry, Cryst. Growth Des., 2012, 12, 499.

30. P. Thuéry, Y. Atoini and J. Harrowfield, Cryst. Growth Des., 2019, 19, 4109 and references therein.

31. K. X. Wang and J. S. Chen, Acc. Chem. Res., 2011, 44, 531.

32. M. B. Andrews and C. L. Cahill, Chem. Rev., 2013, 113, 1121.

33. T. Loiseau, I. Mihalcea, N. Henry and C. Volkringer, Coord. Chem. Rev., 2014, 266-267, 69.

34. P. Thuéry and J. Harrowfield, Dalton Trans., 2017, 46, 13660.

35. K. P. Carter, M. Kalaj, A. Kerridge and C. L. Cahill, CrystEngComm, 2018, 20, 4916.

36. P. Thuéry and J. Harrowfield, Inorg. Chem., 2021, 60, 1683.

37. P. Thuéry, Y. Atoini and J. Harrowfield, Inorg. Chem., 2020, 59, 6953.

38. P. Thuéry, Y. Atoini and J. Harrowfield, Inorg. Chem., 2019, 58, 870.

39. P. Thuéry, E. Rivière and J. Harrowfield, Cryst. Growth Des., 2016, 16, 2826.

40. S. K. Ghosh, A. Ehnbom, K. G. Lewis and J. A. Gladysz, Coord. Chem. Rev., 2017, 350, 30.

41. S. Xu, D. Cao, Y. Liu and Y. Wang, Cryst. Growth Des., 2021, 21, doi: $\underline{10.1021 / \operatorname{acs} . \operatorname{cgd} .1 \mathrm{c} 00776}$

42. APEX3, ver. 2019.1-0, Bruker AXS, Madison, WI, 2019.

43. SAINT, ver. 8.40A, Bruker Nano, Madison, WI, 2019.

44. (a) SADABS, ver. 2016/2, Bruker AXS, Madison, WI, 2016; (b) L. Krause, R. Herbst-Irmer, G. M. Sheldrick and D. Stalke, J. Appl. Crystallogr., 2015, 48, 3.

45. G. M. Sheldrick, Acta Crystallogr., Sect. A, 2015, 71, 3.

46. G. M. Sheldrick, Acta Crystallogr., Sect. C, 2015, 71, 3.

47. C. B. Hübschle, G. M. Sheldrick and B. Dittrich, J. Appl. Crystallogr., 2011, 44, 1281. 
48. A. L. Spek, Acta Crystallogr., Sect. C, 2015, 71, 9.

49. L. J. Farrugia, J. Appl. Crystallogr., 2012, 45, 849.

50. K. Momma and F. Izumi, J. Appl. Crystallogr., 2011, 44, 1272.

51. V. A. Blatov, A. P. Shevchenko and D. M. Proserpio, Cryst. Growth Des., 2014, 14, 3576.

52. P. Thuéry and J. Harrowfield, Inorg. Chem., in the press, DOI: .

53. P. Thuéry and J. Harrowfield, Inorg. Chem., 2015, 54, 10539.

54. P. Thuéry, Cryst. Growth Des., 2016, 16, 546.

55. P. Thuéry and J. Harrowfield, Inorg. Chem., 2016, 55, 2133.

56. P. Thuéry and J. Harrowfield, Cryst. Growth Des., 2017, 17, 2116.

57. P. R. Spackman, M. J. Turner, J. J. McKinnon, S. K. Wolff, D. J. Grimwood, D. Jayatilaka and M. A. Spackman, J. Appl. Cryst., 2021, 54, 1006.

58. S. K. Wolff, D. J. Grimwood, J. J. McKinnon, M. J. Turner, D. Jayatilaka and M. A. Spackman, CrystalExplorer 3.1, University of Western Australia, 2012.

59. (a) R. Taylor and O. Kennard, J. Am. Chem. Soc., 1982, 104, 5063; (b) G. R. Desiraju, Acc. Chem. Res., 1996, 29, 441.

60. A. L. Spek, Acta Crystallogr., Sect. D, 2009, 65, 148.

61. P. Thuéry, Y. Atoini and J. Harrowfield, Inorg. Chem., 2019, 58, 567.

62. P. Thuéry and J. Harrowfield, Cryst. Growth Des., 2014, 14, 1314.

63. L. A. Borkowski and C. L. Cahill, Cryst. Growth Des., 2006, 6, 2241.

64. L. A. Borkowski and C. L. Cahill, Cryst. Growth Des., 2006, 6, 2248.

65. A. T. Kerr and C. L. Cahill, Cryst. Growth Des., 2011, 11, 5634.

66. A. Brachmann, G. Geipel, G. Bernhard and H. Nitsche, Radiochim. Acta, 2002, 90, 147.

67. M. Yada and T. Kijima, Curr. Top. Colloid Interf. Sci., 2002, 5, 49.

68. (a) P. Thuéry and J. Harrowfield, Cryst. Growth Des., 2017, 17, 963; (b) P. Thuéry, Y. Atoini and J. Harrowfield, Inorg. Chem., 2018, 57, 6283; (c) P. Thuéry, Y. Atoini and J. 
Harrowfield, Inorg. Chem., 2018, 57, 7932.

69. P. Thuéry and J. Harrowfield, Inorg. Chem., 2017, 56, 13464.

70. S. Wu, L. Mei, K. Q. Hu, Z. F. Chai, C. M. Nie and W. S. Shi, J. Inorg. Mater., 2020, 35, 243. 


\section{Plumbing the uncertainties of solvothermal synthesis involving uranyl ion carboxylate complexes}

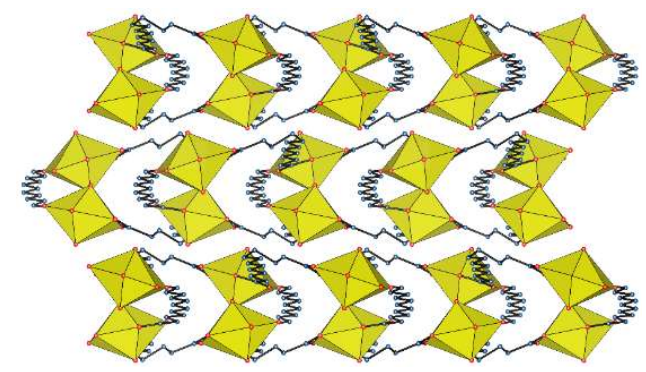

Uranyl ion complexes with long-chain, saturated or unsaturated aliphatic dicarboxylate ligands illustrate how solvo-hydrothermal synthetic conditions sometimes result in the formation of species different from those hoped for. 